\title{
PELATIHAN UNTUK PENGAJUAN PEMBIAYAAN MUDHARABAH PERBANKAN SYARIAH SEBAGAI PENINGKATAN KINERJA UMKM
}

\author{
Mohammad Rizal1, Arini Fitria Mustapita ${ }^{2}$, Arista Fauzi Kartika Sari ${ }^{3}$ \\ 1 Universitas Islam Malang. \\ email: mohammadrizal@unisma.ac.id \\ 2Universitas Islam Malang. \\ email: arinimustapita@unisma.ac.id \\ UUniversitas Islam Malang. \\ email: Aristakartika@unisma.ac.id
}

\begin{abstract}
Financial management is one of the main aspects for the progress of a company. Accounting is a process or way of producing financial information that can be used to make a decision for its users. Implementation methods of Community Service activities is carried out using presentation methods, tutorial systems, and mentoring. The results of the training and mentoring activities for making Islamic banking mudharabah financing proposal aimed at residents of Malang City Kasin Village who are also perpetrators or owners of MSMEs, have been evaluated based on the response and the results of the practices carried out by the participants and assistance for 3 days. This evaluation of community service activities was carried out through a questionnaire and the results of feedback on questions in the questionnaire relating to training and mentoring materials for making bank credit proposal and the enthusiasm of the participants in each question and answer session. The level of understanding of the participants in understanding the material that has been delivered is grouped on a scale of $71 \%-80.99 \%$, then the community service activities are declared "quite good" and there are 3 mudharabah financing proposals available from the results of mentoring activities.
\end{abstract}

Keywords: accounting; financial statements; mudharabah; MSMEs

\begin{abstract}
ABSTRAK
Pengelolaan keuangan adalah satu aspek utama bagi kemajuan sebuah perusahaan. Akuntansi merupakan proses atau cara dalam menghasilkan informasi keuangan yang dapat digunakan untuk pengambilan sebuah keputusan bagi penggunanya. Metode Pelaksanaan kegiatan Pengabdian Pada Masyarakat ini dilakukan dengan menggunakan metode presentasi, sistem tutorial, dan pendampingan. Hasil kegiatan pelatihan dan pendampingan pembuatan proposal pengajuan pembiayaan mudharabah perbankan syariah yang ditujukan pada warga Kelurahan Kasin Kota Malang yang juga sekaligus pelaku atau pemilik UMKM, telah dievaluasi berdasarkan respon dan hasil praktik yang telah dilakukan oleh para peserta dan pendampingan selama 3 hari. Evaluasi atas kegiatan pengabdian masyarakat ini dilakukan melalui kuesioner dan hasil umpan balik atas pertanyaan dalam kuesioner sehubungan dengan materi-materi yang disampaikan serta antusiasme para peserta di setiap sesi tanya jawab. Adapun tingkat pemahaman para peserta dalam memahami materi yang sudah
\end{abstract}


disampaikan dikelompokkan pada skala 71\%-80,99\%, jadi dalam kegiatan pengabdian masyarakat dapat dinyatakan "cukup baik" dan tersedia 3 proposal siap untuk pengajuan pembiayaan mudharabah dari hasil kegiatan pendampingan yang telah dilaksanakan. Berdasarkan hal tersebut maka efektivitas strategi dan tahapan pelaksanaan program terhadap pencapaian tujuan program pengabdian ini dapat dikatakan baik dan tepat, apalagi telah tersedia 3 proposal dari hasil kegiatan pendampingan.

Kata Kunci: akuntansi; laporan keuangan; mudharabah; UMKM

\section{PENDAHULUAN}

\section{Latar Belakang}

Beberapa masalah yang terjadi pada pengusaha mikro salah satunya adalah dari permodalan. Masalah permodalan adalah masalah utama yang dihadapi oleh pengusaha UMKM untuk mengembangkan usaha, meskipun cukup banyak pengusaha yang mempunyai keahlian untuk mengolah usahanya namun tidak adanya modal yang cukup, tentunya tidak akan membuat pengusaha mengembangkan usahanya lebih maju. Jadi modal merupakan faktor yang utama untuk mengembangkan atau memperluas usahanya. Pemahaman ilmu akuntansi adalah salah satu jalan untuk dapat mengembangkan sebuah usaha. Ilmu akuntansi akan memberikan beberapa keuntungan untuk pelaku UMKM, diantaranya: (1) UMKM tersebut bisa mengetahui kinerja keuangan perusahaan, (2) UMKM bisa mengetahui, memilah, dan membedakan harta pemilik dan harta perusahaan, (3) UMKM bisa mengetahui posisi dana baik sumber ataupun penggunaannya, (4) UMKM bisa membuat sistem anggaran yang baik, (5) UMKM bisa menghitung jumlah pajak, dan (6) UMKM bisa mengetahui aliran uang tunai dalam periode tertentu. Dapat disimpulkan bahwa akuntansi membantu membuat laporan keuangan di UMKM (Setyorini,2012), Oleh sebab itu, perlu peran dari banyak pihak untuk membantu berkembangnya dan bangkitnya UMKM. Salah satunya dengan memberikan pengetahuan dan peningkatan kemampuan dalam membuat proposal pengajuan kredit bank dalam rangka mendapatkan permodalan dari bank untuk mengembangkan usahanya. Saat ini, banyak tawaran kredit mikro dari pihak perbankan yang sedang digalakkan dan dipermudah persyaratannya untuk membantu pengembangan UMKM, akan tetapi tetap harus mengajukan proposal pengajuan kredit mikro.

Dalam hal penyaluran dana kepada masyarakat, praktiknya dalam bank syariah berbeda dengan yang dilakukan pada bank konvensional. Perbedaan paling mendasar adalah tidak ada riba atau bunga dalam bank syariah, serta menggunakan sistem pembiayaan bagi hasil (musharakah dan mudharabah). Perbankan syariah memiliki potensi yang sangat besar dalam perekonomian. Sistem perbankan syariah ini sangat cocok untuk mengembangkan UMKM yang memiliki peran strategis dalam menggerakkan pembangunan ekonomi nasional (Wibowo,2005). Dengan 
demikian, kontribusi perbankan syariah dalam pengembangan UMKM sangat diharapkan dapat berjalan dengan lebih maksimal. Salah satu contohnya adalah dengan meningkatkan aksebilitas pembiayaannya yaitu memberikan persyaratan yang lebih mudah serta dilakukan adanya pelatihan dan pendampingan usaha. Perbankan syariah diharapkan dapat terus berkembang dalam memberdayakan usaha mikro kecil dan menengah. (Fatimah:2018).

Para pengusaha di Kelurahan Kasin Kota Malang mempunyai UMKM yang kebanyakan mengalami kesulitan informasi dalam pengajuan kredit mikro ke bank bagi pengembangan usahanya. Banyak pengusaha atau pegiat UMKM yang merasakan kesulitan mengenai ketidaktahuan atau ketidakpahaman mereka akan proposal pengajuan kredit mikro ke bank. Hal itu disebabkan karena latar belakang pendidikan dan minimnya informasi yang mereka dapat. Jika melihat latar belakang tersebut, maka penting untuk dilaksanakan sebuah kegiatan pengabdian masyarakat dalam bentuk pendampingan penyusunan proposal pengajuan kredit bank bagi para pengusaha di Kelurahan Kasin Kota Malang.

Berdasarkan permasalahan tersebut, perlu diadakan kegiatan pelatihan bagi pelaku UMKM dalam hal mengelola keuangan dengan menggunakan akuntansi serta membuat proposal untuk pengajuan mudharabah bank. Program pelatihan yang ditawarkan berupa pelatihan akuntansi sederhana bagi UMKM. Akuntansi yang diajarkan adalah akuntansi sederhana yang disesuaikan dengan keadaan di UMKM namun tidak meyimpang dari standar dan peraturan yang ada. Pelatihan ini ditujukan bagi pelaku UMKM yang menjadi warga Kasin khususnya RT 08. Adanya pelatihan ini diharapkan pelaku UMKM dapat mengetahui perkembangan perusahaan dan dapat memanfaatkan akuntansi guna mendukung kemajuan UMKM mereka (Jusmawi,2017).

\section{Tujuan}

Adapun tujuan dari kegiatan pengabdian masyarakat ini adalah untuk membangun kemampuan dan keahlian pelaku UMKM di Kelurahan Kasin Kota Malang agar dapat menggunakan ilmu akuntansi dalam kegiatan bisnisnya sehingga dapat mengembangkan kinerja keuangan perusahaan. Tujuan pelatihan ini khususnya adalah:

a. Peserta dapat membuat persamaan akuntansi.

b. Peserta dapat dan terampil mencatat transaksi dalam UMKM.

c. Peserta dapat dan terampil menyusun laporan keuangan.

d. Peserta dapat dan terampil menyusun proposal untuk pembiayaan mudharabah di perbankan syariah. 


\section{METODE PELAKSANAAN}

Dalam kegiatan pelaksanaan pengabdian ini, diawali dengan pengumpulan data dan informasi yang relevan. Untuk mendapatkan data dan informasi secara cepat dalam waktu yang terbatas akan mengadopsi metode RRA (Rapid Rural Appraisal). Hal itu relevan dengan tim pengusul yang terdiri dari latar belakang multidisiplin. Kemampuan memahami suatu permasalahan atau isu dengan perspektif lintas disiplin menjadi salah satu keunggulan dari metode ini. Menurut Beebe James (1995), metode RRA menyajikan pengamatan yang dipercepat yang dilakukan oleh dua atau lebih pengamat atau peneliti, biasanya dengan latar belakang akademis yang berbeda. Metode ini bertujuan untuk menghasilkan pengamatan kualitatif bagi keperluan pembuat keputusan untuk merencanakan dan melaksanakan kegiatan. Sugiyono (2013) Jumlah responden yang didapatkan adalah 25 responden sedangkan cara untuk menentukan responden menggunakan metode Cluster Random Sampling atau pengambilan sampel yang dilakukan berdasar kelompok/area tertentu dalam hal ini adalah wilayah Kelurahan Kasin Kota Malang RT 08.

Berjalannya kegiatan Pengabdian Pada Masyarakat dilaksanakan dengan metode presentasi, sistem tutorial, dan pendampingan. Adapun sistematika pelaksanaan kegiatan pengabdian ini adalah sebagai berikut:

a. Tahap 1 (Metode Presentasi): Peserta diberikan materi dan motivasi agar memiliki kemampuan dan kemauan mengenai akuntansi dalam kegiatan bisnisnya. Selain itu, peserta diberikan materi gambaran umum tentang akuntansi UMKM dan peranan akuntansi bagi UMKM.

b. Tahap 2 (Metode Tutorial): Peserta pelatihan diberikan materi akuntansi mulai dari pencatatan sampai dengan menyusun laporan keuangan.

c. Tahap 3 (Metode Pendampingan): Peserta pelatihan diberikan pendampingan untuk diskusi dan tanya jawab permasalahan yang berkaitan mengenai keuangan UMKM.

\section{HASIL DAN PEMBAHASAN}

\section{Proses Pelatihan Akuntansi}

Pemaparan materi berisi tentang persamaan dasar akuntansi, mengenai harta, kewajiban dan modal, dan juga pengertian dan posisi nya dalam akuntansi. Selain itu juga penjelasan mengenai pendapatan, biaya, laba/rugi. Pada awal pelatihan, warga dirasakan sudah kebingungan dengan penjelasan mengenai akuntansi, namun dengan pembawaan dan penjelasan yang dikemas santai oleh para pemateri, sedikit demi sedikit warga Kasin bisa menerima materi yang disampaikan. Contoh transaksi juga di terangkan kepada para warga, untuk dapat semakin memahami istilah-istilah dalam akuntansi. pelatihan akuntansi ini membuat warga menyadari bahwa sebenarnya para peserta sudah banyak melakukan kegiatan akuntansi dalam kehidupan sehari-hari, namun mereka tidak menyadarinya. Karena dalam pemahaman mereka, akuntansi adalah 
tentang keuangan di perusahaan-perusahaan besar dengan omset milyaran.

Pemaparan pelatihan akuntansi yang dilakukan 2 hari tersebut dirasakan pemateri sudah cukup sebagai pengantar untuk melanjutkan ke materi berikutnya, yaitu penyusunan laporan keuangan. Hasil tersebut didapatkan dari hasil latihan soal yang diberikan kepada peserta yang sebanyak $>70 \%$ dapat menjawab soal yang diberikan mengenai materi yang telah dijelaskan. Bagi masyarakat yang belum memahami, di akhir pertemuan, pemateri menyediakan waktu pendampingan dan konsultasi untuk yang ingin belajar lebih perihal akuntansi. Pada waktu tersebut, ada beberapa pemilik UMKM dan juga bahkan anaknya yang bertanya lebih lanjut perihal akuntansi. Hal tersebut menunjukan antusiasme warga Kelurahan Kasin dengan akuntansi.

\section{Penyusunan Laporan Keuangan}

Kegiatan selanjutnya setelah terlaksananya pelatihan akuntansi adalah penyusunan laporan keuangan. Dimana langkah awal metode pelaksanaannya yaitu penyampaian pengetahuan mengenai pembuatan laporan keuangan sederhana kepada para warga yang memiliki UMKM yang berada di Kelurahan Kasin Kota Malang. Kegiatan tersebut dilakukan secara langsung disertai dengan diskusi dan tanya jawab mengenai laporan keuangan. Adapun materi yang disampaikan mengenai pembuatan laporan keuangan sederhana meliputi pembuatan neraca, laporan laba rugi, laporan perubahan ekuitas dan laporan arus kas.

Setelah penyampaian materi selesai, para warga yang memiliki UMKM di Kelurahan Kasin Kota Malang diarahkan untuk membuat laporan keuangan sederhana. Pada sesi ini para warga yang memiliki UMKM diberikan kesempatan untuk mendiskusikan permasalahan yang berkaitan dengan keuangan yang terjadi selama ini. Selanjutnya warga yang memiliki UMKM didampingi dalam memecahkan permasalahan yang dihadapi serta mempraktekkan dan mensimulasikan pembuatan laporan keuangan sederhana yang dimulai dari pencatatan transaksi dan penyusunan laporan keuangan.

Penyusunan laporan keuangan yang dilaksanakan 2 hari tersebut dirasa sudah mampu membekali para warga dalam memahami laporan keuangan. Karena dari hasil yang didapatkan dalam pelatihan selama 2 hari tersebut sebagian besar warga yang memiliki UMKM telah dapat membangun sebuah laporan keuangan sederhana seperti laporan mengenai laba rugi, perubahan ekuitas dan arus kas. Akan tetapi warga masih banyak mengalami kesulitan di bagian neraca, hal ini dikarenakan kurang sabar dan telitinya warga sehingga laporan neraca banyak yang tidak seimbang. Namun secara keseluruhan dapat disimpulkan bahwa para warga yang memiliki UMKM telah mampu dengan cukup baik dalam membuat laporan keuangan sederhana. Dengan tercapainya kegiatan 
pengabdian masyarakat ini diharapkan para warga yang memiliki UMKM di Kelurahan Kasin Kota Malang mempunyai bekal yang cukup dalam pembuatan laporan keuangan sederhana yang berkaitan dengan transaksi dan aktifitas keuangannya.

\section{Penulisan Proposal}

Hasil kegiatan pelatihan dan pendampingan pembuatan proposal pengajuan pembiayaan mudharabah perbankan syariah yang ditujukan pada warga Kelurahan Kasin Kota Malang yang juga sekaligus pelaku atau pemilik UMKM, telah dievaluasi berdasarkan respon dan hasil praktik yang telah dilakukan oleh para peserta dan pendampingan selama 3 hari. Evaluasi atas kegiatan pengabdian masyarakat ini dilakukan melalui kuesioner dan hasil umpan balik atas pertanyaan dalam kuesioner sehubungan dengan materi-materi yang disampaikan serta antusiasme para peserta di setiap sesi tanya jawab. Sedangkan kendala yang dihadapi di lapangan saat pelaksanaan program adalah saat penyampaian materi yang menggunakan istilah-istilah, peserta merasa kesulitan saat menyebutkan atau mengingatnya. Oleh karena itu, narasumber dari tim pelaksana menggunakan kata lain sebagai pengganti dari istilah-istilah tersebut. Kendala tersebut tidak berpengaruh berarti atas tingkat capaian pelaksanaan program. Efektivitas metode pendampingan, monotoring dan evaluasi pelaksanaan program dinilai telah cukup efektif. Hanya saja waktu pelaksanaan program selama 3 hari dirasakan belum memadai. Oleh karena belum terlihat hasil dari 3 proposal yang bakal diajukan ke pihak bank, apakah didanai ataukah tidak, akan tetapi setidaknya program ini telah memberikan kontribusi kepada pihak mitra sesuai dengan tujuan program.

Adapun tingkat pemahaman para peserta dalam memahami materi yang sudah disampaikan dikelompokkan pada skala 71\%-80,99\%, jadi dalam kegiatan pengabdian masyarakat dapat dinyatakan "cukup baik" dan tersedia 3 proposal siap untuk pengajuan pembiayaan mudharabah dari hasil kegiatan pendampingan yang telah dilaksanakan. Berdasarkan hal tersebut maka efektivitas strategi dan tahapan pelaksanaan program terhadap pencapaian tujuan program pengabdian ini dapat dikatakan baik dan tepat, apalagi telah tersedia 3 proposal dari hasil kegiatan pendampingan. Para peserta telah mengetahui mengenai aspek apa saja yang perlu diperhatikan dalam pengembangan usaha dan manajemen permodalan usaha yang baik serta bagaimana membuat proposal pengajuan pembiayaan mudharabah. Hal tersebut ditunjukkan pula dengan hasil 3 proposal rencana pengembangan usaha yang selesai selama proses pendampingan, yakni: dua usaha dibidang jasa dan satu usaha dagang. 
Dengan demikian, perubahan yang dialami mitra program yakni pedagang UMKM di Kelurahan Kasin Kota Malang dapat dikatakan cukup signifikan.

\section{KESIMPULAN}

Dari hasil pembahasan yang telah diuraikan diatas dapat disimpulkan bahwa:

1. Pemaparan pelatihan akuntansi menyimpulkan bahwa didapatkan dari hasil latihan soal yang diberikan kepada peserta yang sebanyak $>70 \%$ dapat menjawab soal yang diberikan mengenai materi yang telah dijelaskan. Bagi masyarakat yang belum memahami, di akhir pertemuan, pemateri menyediakan waktu pendampingan dan konsultasi untuk yang ingin belajar lebih perihal akuntansi. Pada waktu tersebut, ada beberapa pemilik UMKM dan juga bahkan anaknya yang bertanya lebih lanjut perihal akuntansi. Hal tersebut menunjukan antusiasme warga Kelurahan Kasin dengan akuntansi.

2. Penyusunan laporan keuangan dirasa sudah dapat membekali para warga dalam memahami laporan keuangan, Karena hasil yang diperoleh warga yang memiliki UMKM telah dapat membangun sebuah laporan keuangan sederhana seperti laporan mengenai laba rugi, perubahan ekuitas dan arus kas. Akan tetapi para warga masih banyak mengalami kesulitan di bagian neraca, hal ini dikarenakan kurang telitinya warga sehingga laporan neraca banyak yang tidak seimbang. Namun secara keseluruhan dapat disimpulkan bahwa para warga yang memiliki UMKM telah mampu dengan baik dalam membuat laporan keuangan sederhana.

3. Tingkat pemahaman para peserta dalam memahami materi yang sudah disampaikan dikelompokkan pada skala $71 \%-80,99 \%$, jadi dalam kegiatan pengabdian masyarakat dapat dinyatakan "cukup baik" dan tersedia 3 proposal siap untuk pengajuan pembiayaan mudharabah dari hasil kegiatan pendampingan. Berdasarkan hal tersebut maka efektivitas strategi dan tahapan pelaksanaan program terhadap pencapaian tujuan program pengabdian ini dapat dikatakan baik dan tepat, apalagi telah tersedia 3 proposal dari hasil kegiatan pendampingan. Para peserta telah mengetahui mengenai aspek apa saja yang perlu diperhatikan dalam pengembangan usaha dan manajemen permodalan usaha yang baik serta bagaimana membuat proposal pengajuan pembiayaan mudharabah.

\section{SARAN}

Sesuai dengan tujuan program, diharapkan kegiatan pelatihan dan pendampingan serupa dapat diselenggarakan berkelanjutan dalam rangka meningkatkan pengetahuan dan keterampilan para pegiat UMKM dalam menyusun proposal pengajuan pembiayaan mudharabah guna mengakses pembiayaan mudharabah di lembaga perbankan maupun lembaga keuangan lainnya. Peran pihak perbankan pun dituntut dan diharapkan dalam 
meningkatkan literasi keuangan pada masyarakat dan sosialisasi tentang pembiayaan mudharabah UMKM yang mereka sediakan. Dengan proposal yang baik, diharapkan lembaga perbankan dan lembaga keuangan dapat merespon secara positif, tentunya pembiayaan mudharabah yang berhasil diperoleh oleh para pelaku nantinya dapat dimanfaatkan secara bijak untuk meningkatkan usahanya menjadi lebih maju.

\section{DAFTAR RUJUKAN}

Beebe, James. 1995. "Basic Concepts and Thechniques of Rapid Appraisal". Human Organization, Vol. 54, No. 1, Spring.

Bustan, Jusmawi, dkk. 2017. Pelatihan Dan Pendampingan Pembuatan Proposal Pengajuan Kredit Bank Bagi Para Pedagang Pasar Tradisonal Sukawinatan Palembang. Politeknik Negeri Sriwijaya Halaman 9 dari 22 ISSN 2615-8507.

Wibowo, Edy dkk, 2005. Mengapa Memilih Bank Syariah? Bogor: Ghalia Indonesia cet. I.

Fatimah Imaniar, Karnina, 2018. Peran Perbankan Syariah dalam Menggerakkan Usaha Mikro Kecil dan Menengah.

Setyorini, Dhyah, dkk, 2012. Pelatihan Akuntansi UMKM bagi Usaha Mikro Kecil Menengah (UMKM) Untuk Meningkatkan Kinerja Keuangan Perusahaan. Fakultas Ekonomi. Universitas Negeri Yogyakarta.

Sugiyono, 2013, Metodelogi Penelitian Kuantitatif, Kualitatif Dan R\&D. (Bandung: ALFABETA). 